\title{
Characterization and classification of major coconut growing soils in South Eastern Ghats of Tamil Nadu, India
}

\author{
R. Srinivasan*, K.S. Anil Kumar, M. Chandrakala, K.V. Niranjana, N. Maddileti \\ and Rajendra Hegde \\ ICAR-National Bureau of Soil Survey \& Land Use Planning, Regional Centre, Hebbal, Bengaluru-560 024, \\ Karnataka, India
}

(Manuscript Received: 07-12-2020, Revised: 02-04-2021, Accepted: 14-05-2021)

\begin{abstract}
Six soil series representing major coconut growing soils of the Eastern Ghats in Krishnagiri district of Tamil Nadu state, India, were evolved from granite gneiss and alluvium parent materials. Characterization of different soil properties was done using a detailed soil survey at 1:10000 scale. The soils were neutral to moderately alkaline in reaction (7.31 to 9.19), non-saline, poor to moderately well-drained and moderately shallow $(<75 \mathrm{~cm})$ to very deep $(>150 \mathrm{~cm})$ in depth. The soils were sandy to clay in texture, sub-angular blocky to crumb in structure, dark reddish-brown to brown, very low to high in OC content $(0.06$ to $2.70 \%$ ), low to medium in AWC (3.44 to $22.39 \%$ ), low to high in CEC (4.70 to $\left.54.0 \mathrm{cmol}\left(\mathrm{p}^{+}\right) \mathrm{kg}^{-1}\right)$ and having high base saturation (77 to $100 \%$ ). The soils also had sizable amounts of exchangeable sodium (4.29 to $33.46 \%$ ), which was maximum in P5, P6 and P1, and high clay content in P5 and P2. The distribution of $\mathrm{CaCO}_{3}$ in different depths was found to be maximum in P4 and P1. The soil orders identified in the coconut area were Inceptisols, Entisols, Alfisols and Vertisols. Assessment of soil resources and identification of yield-limiting soils factors on coconut could enable of better management and improved productivity.
\end{abstract}

Keywords: Classification, coconut, Eastern Ghats, soil characterization, sustainability

\section{Introduction}

Soil is a vital natural resource for the survival on the earth, and its assessment is a prerequisite for determining soil productivity and the sustainability of the ecosystem. Precise scientific information on characteristics, potentials, limitations, and management of different soils are indispensible for planning and developing soil resources and maintaining the productivity of different plantation crops like coconut (Lal, 2013).

In India, coconut cultivation is an indivisible implant of socio-historical culture as well as an ethnic identity. The livelihood and food security of the major population in Asia and other coastal countries depends mostly on coconut palm (Raghavi et al., 2019). It is estimated that about 12 million people in India are dependent on the coconut sector through cultivation, processing and trading activities. With an annual production of around 17,000 million nuts, the contribution of coconut to the Indian GDP is about ₹ 15,000 crores and a major share of the world's total production is from India, the Philippines and Indonesia (APCC, 2017).

In India, coconut is mainly cultivated in Kerala, Tamil Nadu, West Bengal, Odisha, Karnataka, Maharashtra, and Pondicherry. Of late, coconut cultivation has been introduced to suitable locations in non-traditional states, including Assam, Gujarat, Madhya Pradesh, Rajasthan, Bihar, Tripura, Manipur, and Arunachal Pradesh and the hinterland regions of the coconut growing states. In India, Tamil Nadu tops the list in the productivity of coconut, but production is high in Karnataka and Kerala tops in the area. Tamil Nadu has the highest

*Corresponding Author: srinivasan.surya@gmail.com 
yield among the major coconut growing states with 14,873 nuts, followed by Andhra Pradesh with 13,808 nuts (Singh, 2016).

Coconut is a tropical crop and grows well in hot climates. The palm adapts almost all types of well-drained soils, such as alluvial, red sandy loam, coastal sandy with slightly acidic to neutral soil reaction (Kannan et al., 2017). A decline in soil qualities is primarily responsible for coconut palm's declining health and productivity in the different states (Nair et al., 2018). Major soil parameters like poor drainage, depth, nutrients status and organic carbon had a role in deciding coconut growth and yield in Eastern Ghats. Root penetration and development, important for water uptake, depends on soil physical properties (Avinash et al., 2019).

In Tamil Nadu, it is impossible to increase areawise production in coconut because of water deficit, high labour cost, and utilization of agricultural land for other purposes. Therefore yield has to be increased within the area by using site-specific land resources information and adopting a scientific method of cultivation. A proper understanding of the soil characteristics of the coconut growing soils in Eastern Ghats will be a key indicator for sustainable productivity. Therefore, a case study was undertaken in the Eastern Ghats in Kaveripattinam block, Krishnagiri district of Tamil Nadu, to evaluate the soil properties for better management and productivity.

\section{Materials and methods}

\section{Study area}

The Eastern Ghats located along peninsular India extends over $1750 \mathrm{~km}$ between $77^{\circ} 22^{\prime}$ to $85^{\circ} 20^{\prime}$ E longitude and $9^{\circ} 95^{\prime}$ to $20^{\circ} 74^{\prime}$ ' $\mathrm{N}$ latitude covering states of Tamil Nadu, Karnataka Andhra Pradesh and Odisha. The study was confined to the southern portion of the Eastern Ghats located in Tamil Nadu state. The area lies between $11^{\circ} 47^{\prime} \&$ $12^{\circ} 33^{\prime} \mathrm{N}$ latitude and $77^{\circ} 27^{\prime} \& 78^{\circ} 38^{\prime} \mathrm{E}$ longitude covering Kaveripattinam block of Krishnagiri district (Fig. 1), which belongs to agroecological sub-region (AESR) of 8.2 and covers 29,839 ha. Landscape and soil characteristics are given in Table 1.

\section{Field studies}

A detailed soil survey was carried out on a 1:10,000 scale during 2017-2019. The base map was prepared using a survey of India toposheet (1:50000 scale) and IRS-P6 LISS IV remote sensing image merged with village cadastral map. Soil survey fieldwork was carried out based on imagery characteristics, geology, landform, slope and vegetation. Based on the slope variability, different transect and random observation were studied. Three hundred and fifteen soil profiles were studied in the Kaveripattinam block. Among them, six representative soils series (P1-Nedungal (NDG), P2- Pannanthur (PNT), P3- Papparapatti (PPT), P4- Arasampatti (ASP), P5- Puliyur (PLR) and P6- Kottapatti (KTP) were identified from a coconut growing soils. Soil pits/profiles were excavated on each landform for describing morphological characteristics (Soil Survey Staff, 2003).

\section{Climatic condition}

The study area receives rainfall under the influence of both southwest and northeast monsoons. The mean annual rainfall varied from 750 to $900 \mathrm{~mm}$, and more than 60 to 70 per cent is received during the northeast monsoon (October-December).

Table 1. Site characteristics of study area

\begin{tabular}{|c|c|c|c|c|c|c|c|c|c|}
\hline Pedons & Series & $\begin{array}{l}\text { Area } \\
\text { covering } \\
\text { (ha) }\end{array}$ & $\begin{array}{l}\text { Landform } \\
\text { g }\end{array}$ & MSL & $\begin{array}{l}\text { Slope } \\
(\%)\end{array}$ & Runoff & Drainage & $\begin{array}{l}\text { Nuts } \\
\text { tree }^{-1} \\
\text { yr }^{-1}\end{array}$ & Management \\
\hline $\mathrm{P} 1$ & Nedungal (NDG) & 1125 & Valley floor & 538 & $0-1$ & Slow & Poor & 160 & Good \\
\hline $\mathrm{P} 2$ & Pannanthur (PNT) & 1768 & Valley floor & 431 & $1-3$ & Medium & Somewhat poorly & 140 & Moderate \\
\hline P3 & Papparapatti (PPT) & 1323 & Lower pediment & 429 & $1-3$ & Medium & Moderate & 165 & Good \\
\hline P4 & Arasampatti (ASP) & 814 & Valley floor & 417 & $0-1$ & Slow & Somewhat poorly & 150 & Good \\
\hline P5 & Puliyur (PLR) & 342 & Valley floor & 418 & $0-1$ & Very slow & Poor & 185 & Very good \\
\hline P6 & Kottapatti (KTP) & 3213 & Valley floor & 410 & $0-1$ & Slow & Somewhat poorly & 150 & Good \\
\hline
\end{tabular}




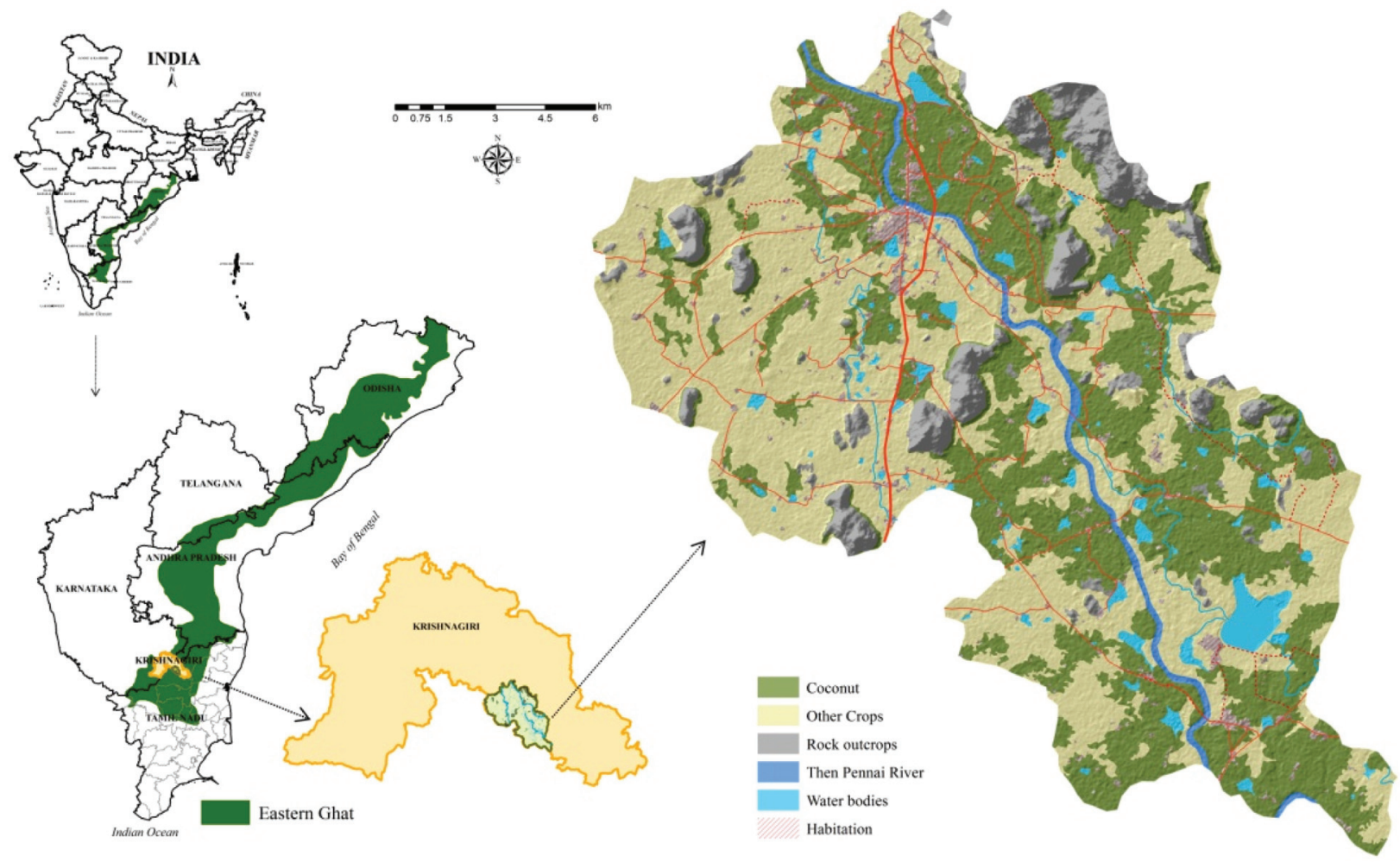

Fig. 1. Location map of the Study area

The mean maximum summer temperature was $37^{\circ} \mathrm{C}$, and the mean minimum temperature was $25.5^{\circ} \mathrm{C}$. The soil temperature class was hyperthermic and moisture regime, "ustic", which is Deccan Plateau, hot semiarid eco-region with mixed red loamy soils and LGP 150 to 180 days.

\section{Soil analysis}

The soil samples were collected from major coconut growing soils from different depths marked as the horizon and kept for air drying. Subsequently, samples were powdered and sieved using a $2 \mathrm{~mm}$ sieve to determine soil physical and chemical characteristics. Soil texture was determined by using the International Pipette Method (Day, 1965). While soil $\mathrm{pH}$ and EC were determined according to Jackson (1973) and Page et al. (1982), soil organic carbon (SOC) was estimated by the wet oxidation method (Walkley and Black, 1934). Available water capacity (AWC) was calculated as the water retained between suction 0.03 and $1.5 \mathrm{MPa}$ using pressure plate apparatus (Klute, 1986). Cation exchange capacity (CEC) was determined using $1 \mathrm{~N}$ ammonium acetate at $\mathrm{pH} 7.0$, whereas base saturation was calculated as the sum of bases divided by CEC and multiplied by 100 . Exchangeable sodium percentage (ESP) is the sodium adsorbed on soil particles, and this was calculated as ESP = (exchangeable $\mathrm{Na} \times 100$ ) / cation exchange capacity. Land capability classes (LCC) and land irrigability classes (LIC) developed for coconut-based soil and site variability (AIS \& LUS, 1970). The soils were classified as per the guidelines given in Keys to Soil Taxonomy (Soil Survey Staff, 2014).

\section{Results and discussion}

\section{Soil morphology}

Detailed morphological characteristics of different soil series are given in Table 2. The soil depth varied from moderately shallow (P4) to very deep (P5). The variations in topography and slope gradient have resulted in the variation in different depths (Srinivasan et al., 2011). The soils are poorly to moderately drained. The surface soil matrix colour varied from dark brown (7.5YR 3/2) to very 
Table 2. Morphological and physical characteristics of the coconut growing soils

\begin{tabular}{|c|c|c|c|c|c|c|c|c|c|c|}
\hline \multirow{2}{*}{\multicolumn{2}{|c|}{$\begin{array}{l}\begin{array}{l}\text { Depth } \\
\text { (cm) }\end{array} \\
\text { Pedon 1: Nedungal series }\end{array}$}} & \multirow[t]{2}{*}{$\begin{array}{l}\text { Colour } \\
\text { (moist) }\end{array}$} & \multirow[t]{2}{*}{ Sand } & \multirow[t]{2}{*}{$\begin{array}{l}\text { Silt } \\
(\%) \\
\end{array}$} & \multirow[t]{2}{*}{ Clay } & \multirow[t]{2}{*}{ Texture } & \multirow[t]{2}{*}{ Structure } & \multicolumn{3}{|c|}{ Consistence } \\
\hline & & & & & & & & $\mathrm{D}$ & M & W \\
\hline $0-18$ & Ap & $10 \mathrm{YR} 3 / 1$ & 54.45 & 18.87 & 26.68 & $\mathrm{scl}$ & $\mathrm{m} 2 \mathrm{sbk}$ & sh & fr & $\mathrm{ms} / \mathrm{mp}$ \\
\hline $18-29$ & Bw1 & $10 \mathrm{YR} 3 / 2$ & 50.23 & 20.26 & 29.51 & $\mathrm{scl}$ & $\mathrm{m} 1 \mathrm{sbk}$ & - & $\mathrm{fr}$ & $\mathrm{ms} / \mathrm{mp}$ \\
\hline $29-42$ & Bw2 & $10 \mathrm{YR} 3 / 2$ & 59.09 & 17.91 & 23.00 & $\mathrm{scl}$ & $\mathrm{m} 1 \mathrm{sbk}$ & - & fr & $\mathrm{ms} / \mathrm{mp}$ \\
\hline $42-91$ & Bw3 & $10 \mathrm{YR} 5 / 2$ & 64.41 & 12.27 & 23.31 & $\mathrm{scl}$ & $\mathrm{f} 1 \mathrm{sbk}$ & - & $\mathrm{fr}$ & $\mathrm{ms} / \mathrm{mp}$ \\
\hline \multicolumn{11}{|c|}{ Pedon 2: Pannanthur series } \\
\hline $0-18$ & Ap & $7.5 \mathrm{YR} 4 / 2$ & 42.58 & 21.48 & 35.94 & $\mathrm{cl}$ & f $1 \mathrm{sbk}$ & $\mathrm{s}$ & vfr & $\mathrm{s} / \mathrm{p}$ \\
\hline $18-32$ & $\mathrm{~A} 2$ & $5 \mathrm{YR} 4 / 3$ & 61.76 & 15.60 & 22.64 & $\mathrm{scl}$ & f $2 \mathrm{sbk}$ & $\mathrm{sh}$ & fr & $\mathrm{ms} / \mathrm{mp}$ \\
\hline $32-50$ & Bt1 & $2.5 \mathrm{YR} 3 / 4$ & 53.37 & 13.95 & 32.68 & $\mathrm{scl}$ & $\mathrm{m} 1 \mathrm{sbk}$ & - & fr & $\mathrm{ms} / \mathrm{mp}$ \\
\hline $50-80$ & $\mathrm{BC}$ & $2.5 \mathrm{YR} 3 / 6$ & 74.54 & 9.52 & 15.94 & sl & m $1 \mathrm{sbk}$ & - & fr & so/po \\
\hline \multicolumn{11}{|c|}{ Pedon 3: Papparapatti series } \\
\hline $0-18$ & Ap & 7.5 YR3/2 & 54.69 & 21.95 & 23.36 & $\mathrm{scl}$ & f $2 \mathrm{sbk}$ & $\mathrm{s}$ & vfr & $\mathrm{ss} / \mathrm{sp}$ \\
\hline $18-42$ & A1 & 7.5 YR $3 / 4$ & 68.27 & 17.60 & 14.12 & sl & f $2 \mathrm{sbk}$ & - & vfr & so/po \\
\hline $42-75$ & $\mathrm{AC}$ & $7.5 \mathrm{YR} 4 / 3$ & 83.40 & 7.87 & 8.73 & ls & $\mathrm{f} 1 \mathrm{cr}$ & - & 1 & so/po \\
\hline $75-105$ & $\mathrm{CA}$ & $7.5 \mathrm{YR} 4 / 3$ & 89.06 & 3.37 & 7.57 & s & $\mathrm{f} 1 \mathrm{cr}$ & - & 1 & so/po \\
\hline \multicolumn{11}{|c|}{ Pedon 4: Arasampatti series } \\
\hline $0-17$ & Ap & $10 \mathrm{YR} \mathrm{3/3}$ & 63.51 & 19.15 & 17.33 & sl & f $2 \mathrm{sbk}$ & 1 & $\mathrm{vfr}$ & so/po \\
\hline $17-42$ & Bw1 & $10 \mathrm{YR} 3 / 2$ & 43.07 & 32.35 & 24.58 & sil & f 2 sbk & - & $\mathrm{fr}$ & so/po \\
\hline $42-73$ & $\mathrm{Bk} 1$ & 10 YR 6/1 & 40.23 & 29.57 & 30.20 & $\mathrm{cl}$ & f $2 \mathrm{sbk}$ & - & fr & $\mathrm{ms} / \mathrm{mp}$ \\
\hline \multicolumn{11}{|c|}{ Pedon 5: Puliyur series } \\
\hline $0-19$ & Ap & 10YR 3/1 & 28.67 & 29.18 & 42.15 & $\mathrm{c}$ & f $1 \mathrm{sbk}$ & 1 & 1 & $\mathrm{vs} / \mathrm{vp}$ \\
\hline $19-49$ & Bss 1 & $10 Y R 3 / 1$ & 27.98 & 25.24 & 46.77 & $\mathrm{c}$ & f $2 \mathrm{sbk}$ & - & $\mathrm{vfr}$ & $\mathrm{vs} / \mathrm{vp}$ \\
\hline $49-75$ & Bss2 & 10YR 3/1 & 24.21 & 26.47 & 49.32 & $\mathrm{c}$ & f $2 \mathrm{sbk}$ & - & $\mathrm{vfr}$ & $\mathrm{vs} / \mathrm{vp}$ \\
\hline $75-110$ & Bss3 & 10YR 2/1 & 17.57 & 25.25 & 57.18 & $\mathrm{c}$ & f $2 \mathrm{sbk}$ & - & $\mathrm{vfr}$ & $\mathrm{vs} / \mathrm{vp}$ \\
\hline $110-158$ & Bss4 & 10YR 2/1 & 16.74 & 25.00 & 58.26 & $\mathrm{c}$ & f $2 \mathrm{sbk}$ & - & $\mathrm{vfr}$ & $\mathrm{vs} / \mathrm{vp}$ \\
\hline \multicolumn{11}{|c|}{ Pedon 6: Kottapatti series } \\
\hline $0-16$ & Ap & $10 \mathrm{YR} 4 / 2$ & 38.85 & 41.38 & 19.77 & sil & $\mathrm{f} 1 \mathrm{sbk}$ & 1 & $\mathrm{vfr}$ & $\mathrm{ss} / \mathrm{sp}$ \\
\hline $16-38$ & Bw1 & $10 \mathrm{YR} 5 / 4$ & 34.68 & 43.30 & 22.02 & sil & f $2 \mathrm{sbk}$ & - & $\mathrm{fr}$ & $\mathrm{ss} / \mathrm{sp}$ \\
\hline $38-75$ & Bw2 & $10 \mathrm{YR} 5 / 3$ & 38.39 & 40.25 & 21.36 & sil & f $2 \mathrm{sbk}$ & - & $\mathrm{fr}$ & $\mathrm{ss} / \mathrm{sp}$ \\
\hline $75-102$ & $\mathrm{BC}$ & 10 YR 5/3 & 56.23 & 27.19 & 16.58 & sl & f $1 \mathrm{sbk}$ & - & $\mathrm{fr}$ & so/po \\
\hline $102-130$ & $\mathrm{CB}$ & $10 \mathrm{YR} 4 / 3$ & 83.42 & 7.81 & 8.77 & ls & $\mathrm{f} 1 \mathrm{sbk}$ & - & $\mathrm{vfr}$ & so/po \\
\hline
\end{tabular}

Texture: s-sand, ls- loamy sandy, sl- sandy loam, sil- silt loam, scl - sandy clay loam; cl-clay loam, c-clay.

Structure: Size (S) - vf - very fine, f - fine, $\mathrm{m}$ - medium, c - coarse; Grade (G) - 0 - structure less, 1- weak, 2 - moderate, 3 - strong; Type (T) cr - crumb, sg - single grain, abk - angular blocky, sbk - sub-angular blocky; Consistence: Dry: s - soft, 1- loose, sh - slightly hard, h - hard; Moist: 1- loose, vfr- very friable, fr - friable, fi - firm, vfi - very firm; Wet: so - non-sticky, ss - slightly sticky, ms - moderately sticky, vs - very sticky; po - non-plastic, ps - slightly plastic, mp - moderately plastic, vp - very plastic

dark gray (10YR 3/1) and dark grayish brown (10YR 4/2), whereas subsoils were reddish-brown to dark red in P2, others were brown (7.5YR 4/3) and black (10YR 2/1). Reddish colour (P2) was attributed to the differential degrees of erosion, lesser content of organic matter and iron oxide content (Patil and Dasog, 1999) and intense leaching of bases resulting in sesquioxides at the surface. The dark colour of P1, P3, P4, P5 and P6 soils were due to different drainage systems, and influences of clay-humus complex and status of organic matter were responsible for colour change in deeper layers 
Table 3. Physico-chemical characteristics of the coconut growing soils

\begin{tabular}{|c|c|c|c|c|c|c|c|c|c|}
\hline $\begin{array}{l}\text { Depth } \\
\text { (cm) }\end{array}$ & $\begin{array}{c}\text { pH } \\
(1: 2.5) \\
\mathrm{H}_{2} \mathrm{O}\end{array}$ & $\begin{array}{c}E C \\
\left(d S ~ m^{-1}\right)\end{array}$ & $\begin{array}{c}\text { AWC } \\
(\%)\end{array}$ & $\begin{array}{l}\text { OC } \\
(\%)\end{array}$ & $\begin{array}{c}\text { CEC } \\
\text { cmol } \\
\left(\mathbf{p}^{+}\right) \mathbf{k g}^{-1}\end{array}$ & $\begin{array}{l}\text { CEC/ } \\
\text { Clay } \\
\text { ratio } \\
\end{array}$ & BS & $\begin{array}{l}\text { ESP } \\
(\%)\end{array}$ & $\begin{array}{c}\mathrm{CaCO}_{3} \\
\mathrm{Eq}\end{array}$ \\
\hline \multicolumn{10}{|c|}{ Pedon 1: Nedungal series } \\
\hline $0-18$ & 7.31 & 1.38 & 12.05 & 2.70 & 13.59 & 0.51 & 100 & 10.68 & 6.74 \\
\hline $18-29$ & 8.60 & 0.55 & 12.89 & 0.34 & 20.97 & 0.71 & 100 & 9.32 & 7.10 \\
\hline $29-42$ & 8.75 & 0.50 & 11.94 & 0.18 & 16.35 & 0.71 & 100 & 13.96 & 6.37 \\
\hline $42-91$ & 8.73 & 0.56 & 12.70 & 0.08 & 16.37 & 0.70 & 100 & 9.25 & 6.37 \\
\hline \multicolumn{10}{|c|}{ Pedon 2: Pannanthur series } \\
\hline $0-18$ & 8.35 & 0.41 & 10.96 & 0.87 & 21.07 & 0.59 & 100 & 4.83 & 4.56 \\
\hline $18-32$ & 8.31 & 0.49 & 9.04 & 0.56 & 14.70 & 0.65 & 100 & 5.58 & 4.08 \\
\hline $32-50$ & 7.91 & 0.66 & 8.03 & 0.45 & 14.11 & 0.43 & 100 & 5.72 & 1.20 \\
\hline $50-80$ & 8.03 & 0.53 & 6.74 & 0.21 & 11.47 & 0.72 & 100 & 8.23 & 0.84 \\
\hline \multicolumn{10}{|c|}{ Pedon 3: Papparapatti series } \\
\hline $0-18$ & 7.86 & 0.47 & 10.55 & 0.87 & 15.09 & 0.65 & 100 & 4.29 & 3.12 \\
\hline $18-42$ & 7.56 & 0.10 & 9.40 & 0.56 & 9.80 & 0.69 & 100 & 8.47 & 0.84 \\
\hline $42-75$ & 7.54 & 0.77 & 5.10 & 0.16 & 6.96 & 0.80 & 100 & 7.40 & 0.72 \\
\hline $75-105$ & 7.55 & 0.37 & 3.44 & 0.06 & 4.70 & 0.62 & 100 & 5.41 & 0.48 \\
\hline \multicolumn{10}{|c|}{ Pedon 4: Arasampatti series } \\
\hline $0-17$ & 8.42 & 0.88 & 10.24 & 1.08 & 12.84 & 0.74 & 100 & 4.84 & 9.84 \\
\hline $17-42$ & 8.54 & 0.65 & 10.59 & 0.21 & 21.85 & 0.89 & 100 & 7.53 & 4.20 \\
\hline $42-73$ & 8.74 & 0.46 & 11.56 & 0.25 & 22.15 & 0.73 & 100 & 6.35 & 24.60 \\
\hline \multicolumn{10}{|c|}{ Pedon 5: Puliyur series } \\
\hline $0-19$ & 8.01 & 1.64 & 7.84 & 1.49 & 43.12 & 1.02 & 100 & 15.64 & 5.28 \\
\hline $19-49$ & 8.36 & 1.10 & 11.44 & 0.41 & 43.22 & 0.92 & 100 & 16.24 & 5.28 \\
\hline $49-75$ & 8.87 & 1.04 & 9.92 & 0.35 & 49.20 & 1.00 & 100 & 21.79 & 6.60 \\
\hline $75-110$ & 9.10 & 1.34 & 18.33 & 0.29 & 51.55 & 0.90 & 100 & 27.67 & 7.20 \\
\hline $110-158$ & 9.19 & 0.53 & 22.39 & 0.29 & 54.00 & 0.93 & 100 & 33.46 & 5.88 \\
\hline \multicolumn{10}{|c|}{ Pedon 6: Kottapatti series } \\
\hline $0-16$ & 8.16 & 0.715 & 12.04 & 0.17 & 13.52 & 0.68 & 100 & 14.23 & 2.88 \\
\hline $16-38$ & 7.85 & 0.495 & 12.67 & 0.23 & 14.70 & 0.67 & 89 & 8.73 & 0.00 \\
\hline $38-75$ & 7.82 & 0.462 & 12.11 & 0.19 & 13.72 & 0.64 & 77 & 8.79 & 0.00 \\
\hline $75-102$ & 7.92 & 0.350 & 9.89 & 0.21 & 11.96 & 0.72 & 89 & 9.53 & 0.00 \\
\hline $102-130$ & 8.17 & 0.198 & 7.28 & 0.14 & 5.78 & 0.66 & 91 & 9.14 & 0.00 \\
\hline
\end{tabular}

(Rao et al., 1995). The different soil colour variations were attributed to different chemical properties (Fe and $\mathrm{Mn}$ ), minerals influences, and textural makeup of soils conditioned by slope position and water movement (Walia and Rao, 1997; Somasundaram et al., 2010). The texture of the soils varied from sandy to clay. This might be due to different combinations of weathering process and soil-forming factors (climate, parent material, topography, biota and vegetation) and processes caused at different times (Srinivasan et al., 2016). The structure of soils was subangular blocky to crumb type. Different blocky structure formation is due to different clay content (Sharma et al., 2004). The dry consistency varied from soft to slightly hard, moist consistency varied from friable to very friable and wet consistency varied from non-sticky/ plastic to very sticky to very plastic. The presence of various structures and consistency of the soils is because of influences of clay fraction and clay 

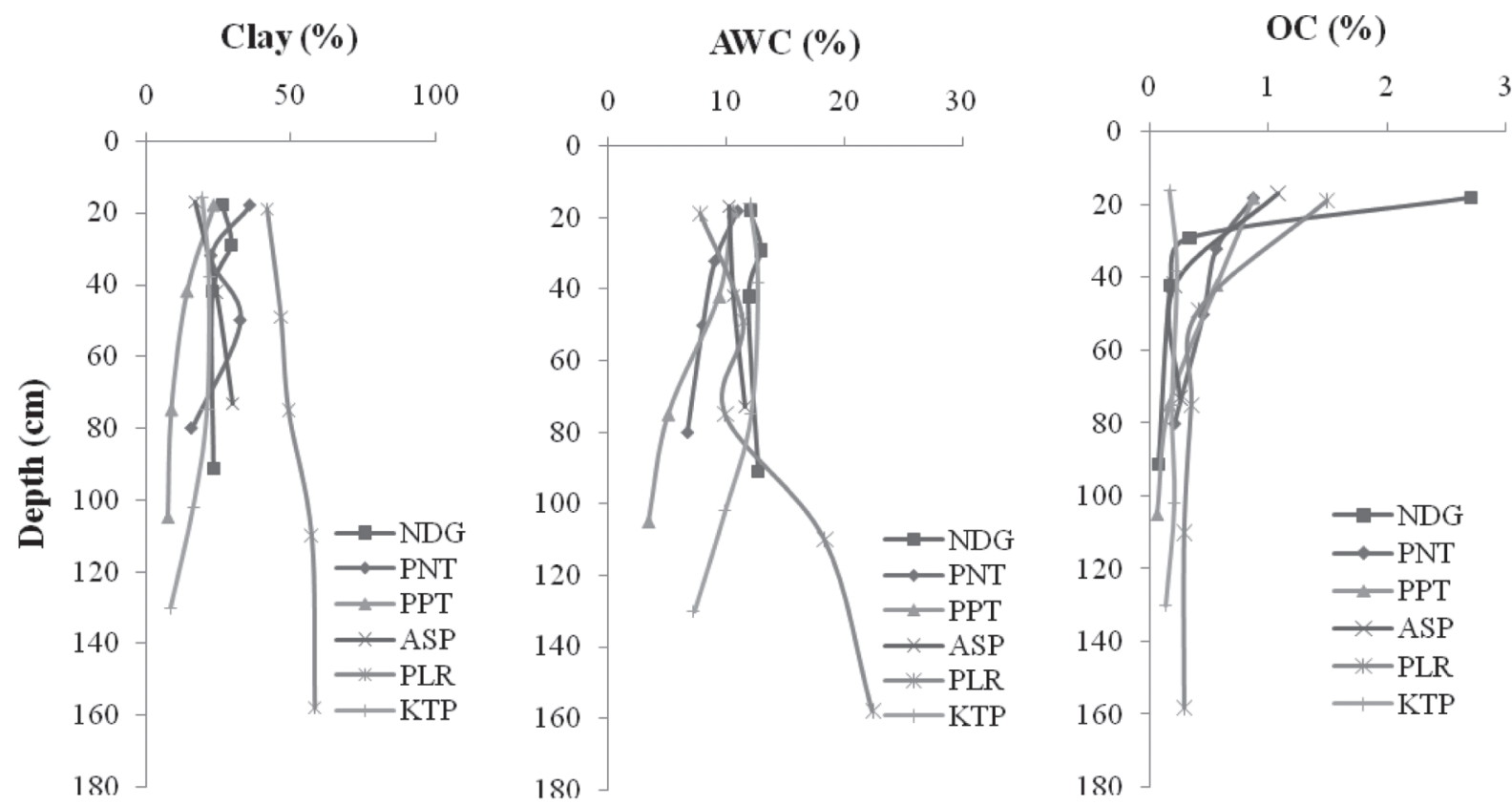

Fig. 2. Depth wise distribution of clay, AWC and OC contents

minerals (Thangasamy et al., 2005). Soil structure was better in all the coconut growing soils except the lower layer of P3, which are better aggregated due to higher organic carbon and relatively lower compaction.

\section{Physical characteristics}

The comprehensive soil physical properties are given in Tables 2 and 3. Particle-size distribution data revealed that the clay content varied from 7.57 to 58.26 per cent. Higher clay content was observed in subsoils of P5 and P1. Silt content in all the pedons showed irregular tendency with different depth, except P2 and P3, which might be due to variation of soil-forming process and action of different weathering process and highest silt content was recorded in P6 and P4 soils, which may be due to higher water fluctuations from different sources (canal, river and well) at different intervals (Srinivasan et al., 2015). Sand distribution was maximum in P3 and P6 soils, ranging from 34.68 to 89.06 per cent sand contributing maximum in texture classes, which could be attributed to the siliceous nature of granite-gneiss parent material. Sandy soils exhibit limitations to coconut production due to poor nutrient retention and water holding capacity, limiting moisture availability to the palm (Arachchi and Somasiri, 1997). These soils have to be properly managed to improve coconut production. Water holding capacity (WHC) of different pedons varied from 3.44 to 22.39 per cent. These variations were due to the difference in depth, clay, silt and organic carbon content. Low WHC in coarse texture (P2 and P3) soils was due to high sand content. The irregular trend of WHC with depth was due to the clay and water movement from the surface to different lower horizons (Fig. 2). Pedons 5,1 and 6 have a higher water holding capacity in the sub-surface horizon than in surface horizons, which might be due to excess clay content and organic matter in the soils (Satish et al., 2018).

\section{Chemical characteristics}

All the series were neutral to moderately alkaline, with $\mathrm{pH}$ varying from 7.31 to 9.19 . This extensive variation was attributed to the nature of the parent material, leaching, presence of $\mathrm{CaCO}_{3}$ and exchangeable $\mathrm{Na}$. Higher $\mathrm{pH}$ in soils of $\mathrm{P} 4$ and P5 were attributed to alkaline hydrolysis of carbonates and bicarbonates in the presence of a high amount of exchangeable $\mathrm{Na}$ (Srinivasan et al., 2019). The presence of exchangeable bases brought by runoff water in surface horizons to subsurface and alternate wet and dry situations results in the 
Table 4. Classification of major coconut growing soils in the study area

\begin{tabular}{|c|c|c|c|c|c|c|}
\hline \multirow[t]{2}{*}{ Pedons } & \multirow[t]{2}{*}{ Series } & \multicolumn{4}{|c|}{ Soil taxonomy } & \multirow[b]{2}{*}{ Family } \\
\hline & & Order & Sub order & Great group & Sub group & \\
\hline $\mathrm{P} 1$ & Nedungal & Inceptisols & Aquepts & Endoaquepts & Typic Endoaquepts & Fine-loamy \\
\hline $\mathrm{P} 2$ & Pannanthur & Alfisols & Ustalfs & Rhodustalfs & Typic Rhodustalfs & Fine-loamy \\
\hline P3 & Papparapatti & Entisols & Orthents & Ustorthents & Typic Ustorthents & Sandy \\
\hline $\mathrm{P} 4$ & Arasampatti & Inceptisols & Ustepts & Calciustepts & Aquic Calciustepts & Fine-loamy \\
\hline P5 & Puliyur & Vertisols & Aquerts & Natraquerts & Typic Natraquerts & Fine \\
\hline P6 & Selakuttapatti & Inceptisols & Ustepts & Haplustepts & Fluventic Haplustepts & Fine-silty \\
\hline
\end{tabular}

deposition of soluble salts in surface soils (Ram et al., 2010). All the soil series had shown low EC values varying from 0.10 to $1.64 \mathrm{dS} \mathrm{m}^{-1}$, indicating non-saline nature. The low EC may be due to excess water movement and frequently leaching of base cations by percolating water. This could also indicate the low status of cations and anions, which are important in coconut nutrition (Nair et al., 2018).

The organic carbon content of the soils was found low to high on the surface $(0.17$ to $2.70 \%)$ and low to medium in subsoils (0.06 to $0.56 \%$ ). Surface soils recorded higher organic carbon content than sub-surface soils due to increased litter, crop residues, and the addition of manure and fertilizers to the surface soils. Organic carbon content decreased with depth in all the pedons (Fig. 2). Brown to dark brown surface colour in all these series compared to sub-surface horizons was due to deposition of organic matter. Further, the organic $\mathrm{C}$ was leached to lower layers and percolating water leading to its loss from the surface soils (Leelavathi et al., 2009). Cation exchange capacity (CEC) and base saturation (BS) varied from 4.70 to $54.0 \mathrm{cmol}$ $\left(\mathrm{p}^{+}\right) \mathrm{kg}^{-1}$ and 77 to 100 per cent, respectively, which corresponded to the clay content, organic $\mathrm{C}$ content and also type of clay mineral present in the different horizons of soils. The higher base saturation observed in almost all pedons might be due to the higher amount of $\mathrm{Ca}^{2+}$ occupying exchange sites on the colloidal complex. The differences in base saturation indicate the degree of leaching (Sharma et al., 2011). CEC/clay ratio varied from 0.43 to 1.02 , which indicated the nature of clay minerals in different pedons. The exchangeable sodium percentage (ESP) ranged from 4.29 to 33.46 per cent, with high ESP in lower layers of P5 and P1. This may be due to the occurrence of sodium ions enriched through runoff water and parent materials. The high $\mathrm{CaCO}_{3}$ may be due to the climate responsible for the pedogenic processes resulting in the depletion of $\mathrm{Ca}^{2+}$ ions from the soil solution in $\mathrm{CaCO}_{3}$ with the concomitant increase in ESP with different depths of soils. Free $\mathrm{CaCO}_{3}$ percentage ranged from 0.0 to 24.6 per cent, and the highest $\mathrm{CaCO}_{3}$ content was noticed in $\mathrm{P} 4$ soil, which might be due to river flow accumulation and climate change effect on pedogenic processes resulting in the depletion of $\mathrm{Ca}^{2+}$ ions from calcite parent materials (Khanday et al., 2017).

\section{Soil classification}

Based on the variation in soil development and soil characteristics, different soil series were identified, and family level classification was carried out as per the keys to soil taxonomy (Table 4). These soils were classified in the order Entisols (P3), Inceptisols (P1, P4 and P6), Alfisols (P2) and Vertisols (P5). Pedon 3, without any diagnostic horizon, was classified as Entisols. Pedons 1, 4 and 6 have cambic $(\mathrm{Bw})$ subsurface diagnostic horizons and were classified under Inceptisols. The P2 series having an argillic horizon with ochric epipedon and were classified under Alfisols. Pedons 5 was placed under Typic Natraquerts at sub-group level due to the presence of sodic horizon (ESP $>15)$ and showed intersecting slickensides, wedge-shaped aggregates, more than $30 \%$ clay in all the horizons and cracks $(2-5 \mathrm{~cm}$ wide) in the $\mathrm{B}$ horizon resulting in the development of Bss horizon, were classified under Vertisols. The development of different kinds of soils in a single region may be influenced by variation in climatic condition, geology, sloping position, water movement and vegetation over time (Srinivasan et al., 2013). 
Table 5. Evaluations and management of coconut growing soils

\begin{tabular}{|c|c|c|c|c|c|}
\hline Pedons & Series & $\mathrm{LCC}$ & LIC & Major limitations & Suitable management \\
\hline 1. & Nedungal & IIws & $4 w s$ & $\begin{array}{l}\text { Leveled low land with moderately } \\
\text { deep, slight erosion, slow runoff, } \\
\text { poor drainage and low soil nutrients } \\
\text { status and high sodium content. }\end{array}$ & $\begin{array}{l}\text { Adopting suitable drainage system and } \\
\text { deep pit plantation will be more sustainable. } \\
\text { Addition of appropriate quantity of } \\
\text { manures and fertilizers will get more yields. }\end{array}$ \\
\hline 2. & Pannanthur & IIse & $2 \mathrm{sw}$ & $\begin{array}{l}\text { Very gently slope with moderately } \\
\text { deep depth, slight erosion, medium } \\
\text { runoff and low AWC \& poor } \\
\text { nutrients status. }\end{array}$ & $\begin{array}{l}\text { Improving soil quality by addition different } \\
\text { manures and management systems. } \\
\text { Adopting appropriate soil and water } \\
\text { conservation measures and nutrient } \\
\text { management techniques. }\end{array}$ \\
\hline 3. & Papparapatti & IIIse & $2 \mathrm{st}$ & $\begin{array}{l}\text { Very gently slope with deep depth, } \\
\text { slight erosion, medium runoff and } \\
\text { low AWC \& poor nutrients status. }\end{array}$ & $\begin{array}{l}\text { Adopting appropriate soil and water } \\
\text { conservation measures. Application of } \\
\text { organic manures and adopting integrated } \\
\text { nutrient management (INM). }\end{array}$ \\
\hline 4. & Arasampatti & IIs & $2 \mathrm{w}$ & $\begin{array}{l}\text { Leveled low land with moderately } \\
\text { shallow, slow runoff, somewhat } \\
\text { poorly drainage and low soil } \\
\text { nutrients status and high sodium } \\
\text { content. }\end{array}$ & $\begin{array}{l}\text { Adopting suitable drainage system and deep } \\
\text { plantation techniques. Application of } \\
\text { optimum dose of manures and fertilizers. }\end{array}$ \\
\hline 5. & Puliyur & IIsw & $3 w t$ & $\begin{array}{l}\text { Leveled low land with very deep, } \\
\text { slow runoff, poor drainage and low } \\
\text { soil nutrients status and high } \\
\text { sodium content. }\end{array}$ & $\begin{array}{l}\text { High clay rich soils should add excess } \\
\text { organic manures and suitable drainage } \\
\text { system. Application of different organic } \\
\text { manures and remediation of deficient } \\
\text { nutrients. }\end{array}$ \\
\hline 6. & Kottapatti & IIsw & $2 w t$ & $\begin{array}{l}\text { Leveled low land with very } \\
\text { deep depth, slight erosion, } \\
\text { slow runoff, somewhat poorly } \\
\text { drainage and low soil nutrients } \\
\text { status. }\end{array}$ & $\begin{array}{l}\text { Addition of excess organic measures (FYM, } \\
\text { vermicompost, coir pith and compost etc) } \\
\text { improving the soil quality and fruiting } \\
\text { yield. Application of balanced fertilizer in } \\
\text { different age of the coconut system. }\end{array}$ \\
\hline
\end{tabular}

\section{Interpretative groupings}

Soils were interpreted and evaluated for land capability and irrigability for coconut plantation considering climatic conditions, soil depth, texture, drainage, slope, $\mathrm{AWC}, \mathrm{CaCO}_{3}$ and exchangeable sodium percent. The categorization of soils into capability classes and subclasses were done mainly based on the number and severity of several limitations viz., erosion risk (e), wetness (w), rooting zone (soils) limitations (s) and climatic limitations (c). The major coconut growing soils placed in the land capability class of II, except P3, was grouped in IIIse (Table 5). Land irrigability assessment categorized different coconut growing soils into
2 to 4 with different subclasses wetness, topography and soil limitations. Major constraints encountered for coconut cultivation are shallow depth, poor drainage, high sodium salts, low AWC and poor soil fertility. Appropriate site-specific soil and water conservation measures and the addition of organic manures and fertilizers will overcome the limitations and improve the productivity of coconut plantations in the Eastern Ghat regions.

\section{Conclusion}

Extensive low soil depth, poor drainage, low soil organic matter, high sodium level and widespread nutrient deficiencies were major 
limitations of coconut production in the Eastern Ghat regions. Therefore, adopting appropriate sitespecific technologies will be achieving sustainable productivity. The study will help identify potential areas and yield-limiting soil parameters for the scientific cultivation of coconut and ensure sustainable production in this region.

\section{References}

AIS \& LUS. 1970. Soil Survey Manual, All India Soil and Land Use Survey Organisation, IARI, New Delhi. pp. 1-63.

APCC (Asian and Pacific Coconut Community). 2017. Coconut Statistical Yearbook 2015 APCC Publishers,

Arachchi, L.P.V. and Somasiri, L.L.W. 1997. Use of coir dust on the productivity of coconut on sandy soils. $\operatorname{Cocos} \mathbf{1 2}$ : 54-71.

Avinash, R.K., Anil Kumar, K.S., Karthika, K.S., Kalaiselvi, B. and Sujatha, K. 2019. Coconut-growing soils in southern Karnataka: Characterization and classification. Journal of Plantation Crops 47(2): 96-106.

Day, P.R. 1965. Particle fractionation and particle size analysis. In: Methods of Soil Analysis, Part 1, (Ed.) C. A. Black, Madison, Wisc.: American Society of Agronomy. pp. 545-567.

Jackson, M.L. 1973. Soil Chemical Analysis. Prentice Hall of India (Pvt.) Ltd., New Delhi. 485p.

Kannan, B., Ragunath, K.P., Kumaraperumal, R., Jagadeeswaran, R. and Krishnan. R. 2017. Mapping of coconut growing areas in Tamil Nadu, India using remote sensing and GIS. Journal of Applied and Natural Science 9(2): 771-773

Khanday, M., Ram, D., Wani, J.A., Raina, S.K. and Ali, T. 2017. Characterization, classification and evaluation of soils of Namblan sub-catchment of Jhelum basin in Srinagar district for their rational use. Journal of the Indian Society of Soil Science 65: 16-23.

Klute, A. 1986. Water retention laboratory methods. In: Methods of Soil Analysis, Part 1: Physical and Mineralogical Methods, 2nd Ed, Madison,Wisc.: American Society of Agronomy, Soil Science Society of America. pp. 635-662.

Lal, R. 2013. Soil and Sanskriti. Journal of the Indian Society of Soil Science 61: 267-274.

Leelavathi, G.P., Naidu, M.V.S., Ramavatharam, N. and Karuna Sagar, G. 2009. Studies on genesis, classification and evaluation of soils for sustainable land use planning in Yerpedu Mandal of Chittoor district, Andhra Pradesh. Journal of the Indian Society of Soil Science 57(2): 109-120.

Nair, K.M., Anil Kumar, K.S., Ramesh Kumar, S.C., Ramamurthy, V., Lalitha, M., Srinivas, S., Arti Koyal,
Parvathy, S., Sujatha, K., Shivanand, Hegde, R. and Singh, S.K. 2018. Coconut-growing soils of Kerala: 1. Characteristics and classification. Journal of Plantation Crops 46 (2):75-83.

Page, A.L., Miller, R.H. and Keeney, D.R. 1982. Methods of Soil Analysis, Part 2, $2^{\text {nd }}$ Ed., Soil Science Society of America, Madison, USA.

Patil, P.L. and Dasog, G.S. 1999. Genesis and classification of ferruginous soils in Western Ghats and coastal region of North Karnataka. Agropedology 9: 1-15.

Raghavi, M.D., Sakthi Bala, M., Surender, S., Lokesh, P. and Kalidas, K. 2019. Review on area, production and productivity of coconut in India. IMPACT: International Journal of Research in Business Management 7(1): 1-6.

Ram, R.L., Sharma, P.K., Jha, P., Das, N. and Ahmed, N. 2010. Characterization and classification of Nagarjunasagar catchment in Shorapur taluk of Gulbarga district in Karnataka. Agropedology 20: 112-123.

Rao, B.R.M., Venkataramaiah, K. and Sharma, S.K. 1995. Genesis, morphology and classification of soils of Andhra Pradesh: A monograph (Ed.) Subba Rao, Andhra Pradesh Agricultural University and Hyderabad chapter of Indian Society of Soil Science. pp. 1-115.

Satish, S., Naidu, M.V.S., Ramana, K.V., Munaswamy, V., Prabhakara Reddy, G. and Sudhakar, P. 2018. Characterization and classification of the soils of Brahmanakotkur Watershed in Kurnool district of Andhra Pradesh. Journal of the Indian Society of Soil Science 66(4): 351-361.

Sharma, R.C., Mandal, A.K., Singh, R. and Singh, Y.P. 2011. Characteristics and use potential of sodic and associated soils in CSSRI experimental farm, Lucknow, Uttar Pradesh. Journal of the Indian Society of Soil Science 59: 381-387.

Sharma, S.S., Totawat, K.L. and Shyampura, R.L. 2004 Characterization and classification of salt-affected soils of southern Rajasthan. Journal of the Indian Society of Soil Science 52: 209-213.

Singh, A.K. 2016. Coconut development in India - The status. Indian Coconut Journal 10: 5-10.

Soil Survey Staff. 2003. Soil Survey Manual. USDA Handbook No. 18, Jodhpur, India: Scientific Publishers.

Soil Survey Staff. 2014. Key to Soil Taxonomy. 12th Edition. USDA Natural Resource Conservation Services. Washington, DC. p. 372.

Somasundaram, J., Nataranjan, S., Mathan, K.K., Kumar, V.A. and Sivasamy, R. 2010. Characterization of some typical pedons in lower Vellar basin of Pudukottai district in Tamil Nadu. Agropedology 20: 103-111.

Srinivasan, R., Mukhopadhyay, S., Nayak, D.C. and Singh, S.K. 2015. Characterization, classification and evaluation 
of soil resources in coastal eco-system- A case study of Gosaba Block (Part), South 24 Parganas, West Bengal. Agropedology 25(02): 195-201.

Srinivasan, R., Natarajan, A., Anil Kumar, K.S. and Kalaivanan, D. 2011. Land suitability evaluation of soils of Dakshina Kannada district of Karnataka for cashew production. Journal of Plantation Crops 39(2): 325-329.

Srinivasan, R., Natarajan, A., Anil Kumar, K.S. and Kalaivannan, D. 2013. Characterization of major cashew growing soils of Dakshina Kannada district of Karnataka. Agropedology 23: 59-64.

Srinivasan, R., Rajendra Hegde, Karthika, K.S., Maddileti, N. and Singh. S.K. 2019. Effect of Different land uses on soil pedogenic properties and sodicity development in Krishnagiri Reservoir Project Dam Catchment in Tamil Nadu. Journal of Soil Salinity and Water Quality 11(1): 10-17.
Srinivasan, R., Singh, S.K., Nayak, D.C. and Naidu, L.G.K. 2016. Characterization, classification and evaluation of cashew growing soils in coastal Odisha for sustainable production. Agropedology 26(02): 178-188.

Thangasamy, A., Naidu, M.V.S., Ramavatharam, N. and Raghava Reddy, C. 2005. Characterization, classification and evaluation of soil resources in Sivagiri microwatershed of Chittoor district in Andhra Pradesh for sustainable land use planning. Journal of the Indian Society of Soil Science 53: 11-21.

Walia, C.S. and Rao, Y.S. 1997. Characteristics and classification of some soils of Trans-Yamuna plains. Journal of the Indian Society of Soil Science 45: 156-162.

Walkley and Black, C.A. 1934. An examination of digestion method for determining organic carbon in soil, effect of variation in digestion conditions and of inorganic soil constituents, Soil Science 63: 251-263. 